\title{
APLIKASI AUGMENTED REALITY SEBAGAI MEDIA INFORMASI MUSEUM FATAHILLAH DAN MUSEUM WAYANG MENGGUNAKAN METODE MARKERLESS
}

\author{
Nadia Muis Farhany ${ }^{1)}$, Septi Andryana ${ }^{2)}$, Ratih Titi Komalasari ${ }^{3)}$ \\ 1,2,3) Fakultas Teknologi Komunikasi dan Informatika, Universitas Nasional \\ e-mail: nadiamuisfarhany@ gmail.com ${ }^{1)}$, septi.andryana@ civitas.unas.ac.id ${ }^{2)}$, ratih.titi@ civitas.unas.ac.id ${ }^{3)}$
}

\begin{abstract}
The Fatahillah Museum and the Wayang Museum are historical museums located in the old city area of Jakarta that is visited by many. But the problem that occurs at this time is the lack of media to reintroduce the history and knowledge of the establishment of the Fatahillah Museum and the Wayang Museum So, in this study, an Androidbased Augmented Reality application was designed as a media of information using the Markless 3D Object Tracking method. This museum Augmented Reality application provides features that can attract users in searching for information. The results obtained are the AR application can be an alternative to the problem caused by the lack of information media, from the average use of the application obtained $93.2 \%$ which means that the application designed has been following the wishes of the user.
\end{abstract}

Keywords: Augmented Reality, Android, 3D Object Tracking

\begin{abstract}
ABSTRAK
Museum Fatahillah dan Museum Wayang merupakan Museum Sejarah yang berada dikawasan kota tua Jakarta yang banyak dikunjungi. Namun masalah yang terjadi saat ini adalah kurangnya media untuk mengenalkan kembali sejarah dan pengetahuan berdirinya Museum Fatahillah dan Museum Wayang Maka pada penelitian ini, dirancanglah sebuah aplikasi Augmented Reality berbasis Android sebagai media informasi menggunakan metode markerless 3D Object Tracking. Aplikasi Augmented Reality museum ini menyediakan ftur yang dapat menarik pengguna dalam mencari informasi. Hasil yang didapat yaitu Aplikasi $A R$ dapat menjadi alternatif dari masalah yang disebabkan oleh kurangnya media informasi, dari hasil rata - rata penggunaan aplikasi didapat 93,2\% yang mengartikan bahwa aplikasi yang dirancang telah sesuai dengan keinginan user.
\end{abstract}

Kata Kunci: Augmented Reality, Android, 3D Object Tracking

\section{PENDAHULUAN}

$\mathrm{M}$ USEUM Fatahillah dan Museum Wayang merupakan museum sejarah yang berada dikawasan Kota Tua Jakarta. Sampai saat ini keberadaan 2 museum tersebut sangat digemari oleh banyak masyarakat di Jakarta bahkan turis Mancanegara yang menjadikan Museum Fatahillah dan Museum Wayang sebagai sarana wisata, tetapi yang terjadi saat ini yaitu kurangnya minat keingintahuan para masyarakat yang berkunjung kesana [1]. Perkembangan teknologi AR saat ini telah memberikan banyak kontribusi kedalam berbagai bidang meliputi periklanan dan pemasaran, arsitektur dan konstruksi, hiburan, medis, militer, dan perjalanan wisata [2]. Salah satu implementasi AR di bidang media informasi yaitu pemanfaatan AR dalam museum [3]. Namun masalah yang terjadi saat ini adalah kurangnya media untuk mengenalkan kembali sejarah dan pengetahuan berdirinya Museum Fatahillah dan Museum Wayang, karena menurunnya minat membaca masyarakat terhadap sejarah yang ada di Jakarta.

Augmented reality adalah teknologi yang menggabungkan benda maya dua dimensi dan ataupun tiga dimensi ke dalam sebuah lingkungan nyata [4][5]. Dari penelitian terdahulu, 3D Object yang ditampilkan tidak mempaparkan penjelasan berupa teks [6]. Dari penelitian lain, metode 3D Object juga digunakan untuk memberikan informasi terkait object museum Bali [7].pada penelitian sejenis, tidak ada penjelasan berupa video tentang 3D Object [8]. Pada penelitian Yudha Akbar Pramana, Komang Candra Brata, Adam Hendra Brata, informasi yang diberikan hanya berupa 3D Object [9]. Pada 
penelitian yang dilakukan oleh Ni Made Sudiartini, I Gede Mahendra Darmawiguna, I Made Gede Sunarya aplikasi Augmented reality dengan metode markerless yang menjelaskan narasi berupa audio suara [10].

Maka berdasarkan penelitian terdahulu metode 3D Object sangat sesuai dalam penelitian Museum Fatahillah dan Museum Wayang. Solusi yang digunakan yaitu dilakukan Perancangan sebuah aplikasi Augmented reality berbasis Android sebagai media informasi menggunakan metode markerless, yang bertujuan sebagai salah satu pembelajaran alternatif berbasis teknologi.dengan sebuah penjelasan berupa teks dan video animasi yang dapat menjadi tambahan informasi dari sebuah museum. adanya aplikasi ini dapat membuat penyampaian informasi menjadi lebih menarik dan mampu membuat para pengguna merasa tertarik untuk menggunakannya, dengan begitu dapat membuat pengguna mengetahui sebuah informasi yang terdapat pada aplikasi.

\section{Metode Penelitian}

Pada penelitian ini digunakan metode Markerless 3D Object Tracking untuk menampilkan Museum Fatahillah dan Museum Wayang yang mempunyai kelebihan Object dapat muncul tanpa menggunakan marker nyata [11].

\section{A. Metode Markerless}

Augmented reality memiliki dua metode yang sangat signifikan berkembang dalam beberapa tahun belakangan ini yaitu marker based tracking dan markerless augmented reality [12]. Markerless Augmented reality merupakan metode dalam pengembangan AR tanpa harus menggunakan marker. Markerless digunakan dalam pelacakan objek yang ada pada dunia nyata untuk diproyeksikan ke dalam dunia maya tanpa memiliki marker yang spesial [13]. Markerless AR dibagi menjadi dua teknik, yaitu sebagai berikut [14].

1) Pose Tracking Teknik Pose Tracking bekerja dengan cara mengamati lingkungan yang static dengan perangkat keras augmented reality yang bergerak.

2) Pattern Matching Teknik Pattern Matching mirip dengan tipe Marker Based Augmented reality, namun marker diganti dengan suatu gambar biasa.

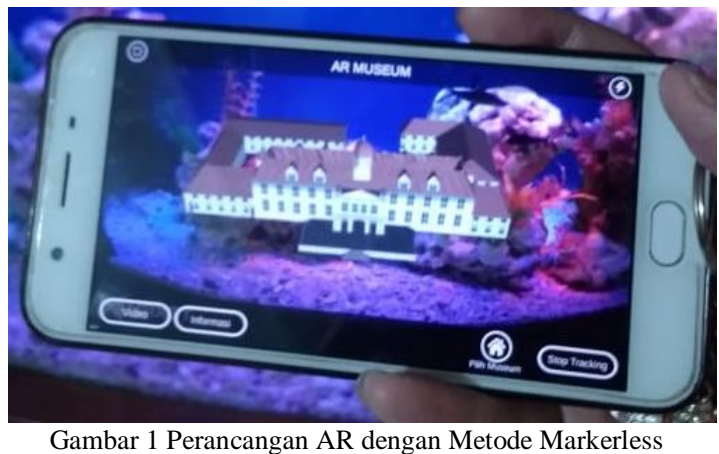

Penerapan AR dengan metode Markerless ditunjukkan pada Gambar 1, metode markerless dapat langsung diterapkan sebab tidak dibutuhkan penanda khusus untuk menampilkan objek yang dirancang.

\section{B. Unity $3 D$}

Unity adalah sebuah tools yang terintegrasi untukmembuat bentuk objek 3D pada Video Games, atau untuk konteks interaktif lain seperti Visualisas Arsitektur atau animasi 3D real-time. Lingkungan dari pengembangan Unity 3D berjalan pada Microsoft Windows dan Mac Os X, serta permainan yang dibuat oleh Unity dapat berjalan pada Windows, Mac, Xbox 360, Playstation 3, Wii, iPad, iPhone, dan tidak ketinggalan pada platform Android [14].

\section{Sketchup}

SketchUp adalah program yang digunakan untuk berbagai proyek pemodelan 3D seperti arsitektur, desain interior, arsitektur lansekap, dan desain video game. Sketcup juga dapat digunakan untuk membuat gerakan kamera animasi pada Object. 


\section{Analisis Kebutuhan Perangkat}

Dalam penelitian ini penulis menggunakan beberapa perangkat yang membantu untuk mengoperasikan aplikasi.

1. Kebutuhan perangkat keras (hardware) yang digunakan: Laptop Processor Intel CORE i5, VGA NVIDIA, Hardisk 1 TB, RAM 8 GB.

2. Kebutuhan perangkat lunak (software) yang dignakan, yaitu Spesifikasi perangkat lunak yang digunakan untuk merancang aplikasi AR berbasis Android, yaitu; Unity 2018.3.14f1 (64-bit), Sketchup dan SDK MAXST.

\section{E. Rancangan Aplikasi}

Rancangan Aplikasi yang digunakan digambarkan melalui flowchart yang mana ditujukan untuk mempermudah penjelasan dari alur sistem yang dibangun.

Digunakan flowchart dalam perancangan AR, yang dijelaskan sebagai berikut [2].

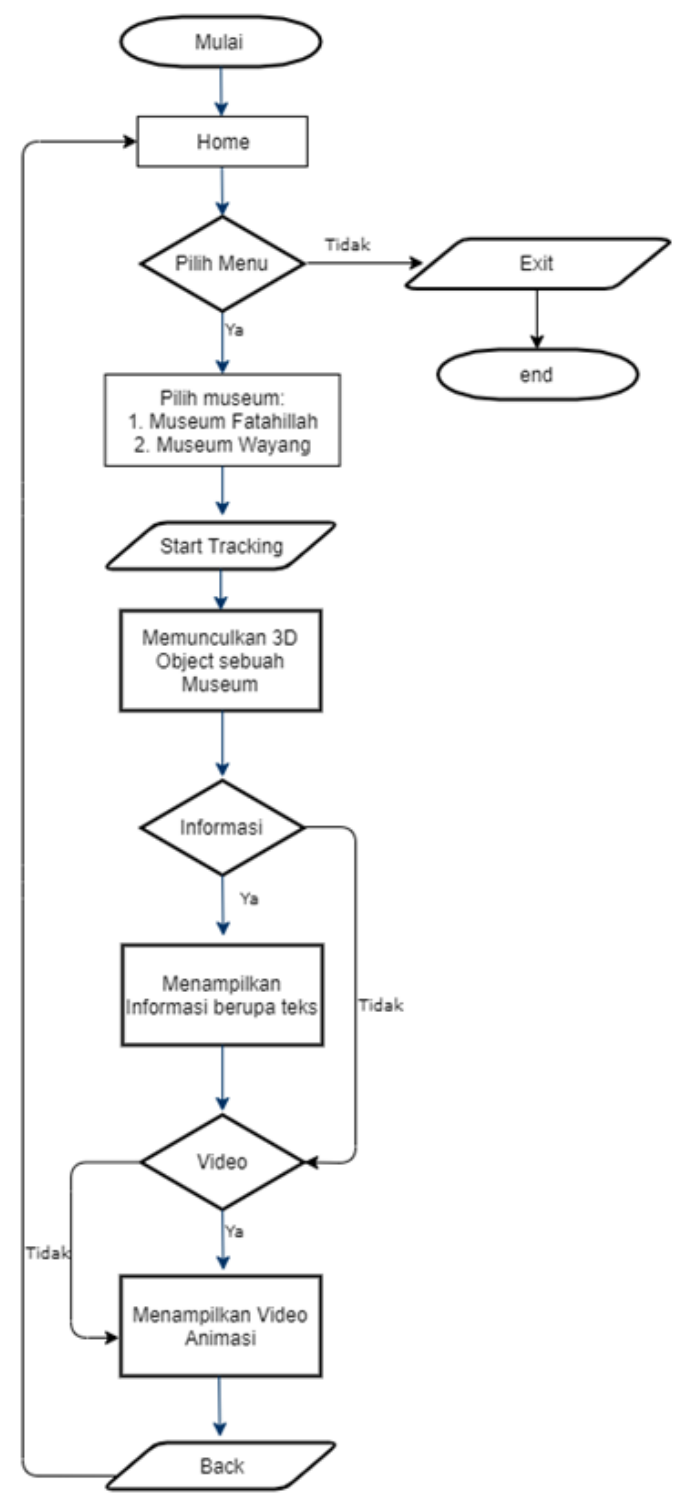

Gambar 2. Flowchart Rancangan Aplikasi

Gambar 2 menampilkan flowchart dari aplikasi yang dirancang, dengan langkah sebagai berikut.

1. Langkah pertama dilakukan dengan masuk dan memilih jenis museum yang disediakan, yaitu museum Fatahillah dan museum Wayang.

2. Tekan Start Tracking button untuk menampilkan 3D Object museum.

3. User dapat memilih untuk menampilkan informasi atau hanya ingin menampilkan video terkait 
museum yang dipilih atau memilih untuk menampilkan semuanya.

4. Kemudian user memilih untuk kembali ke menu utama.

\section{HASIL DAN PEMBAHASAN}

\section{A. Storyboard}

Pada storyboard ditampilkan aplikasi yang dirancang sebagai media penyampaian informasi berupa visual yang menampilkan objek museum Fatahillah dan museum Wayang. Aplikasi ini digunakan sebagai alternatif dari masalah yang diangkat, yaitu kurangnya media penyampaian informasi terkait museum.

TABEL I

STORYBOARD APLIKAS

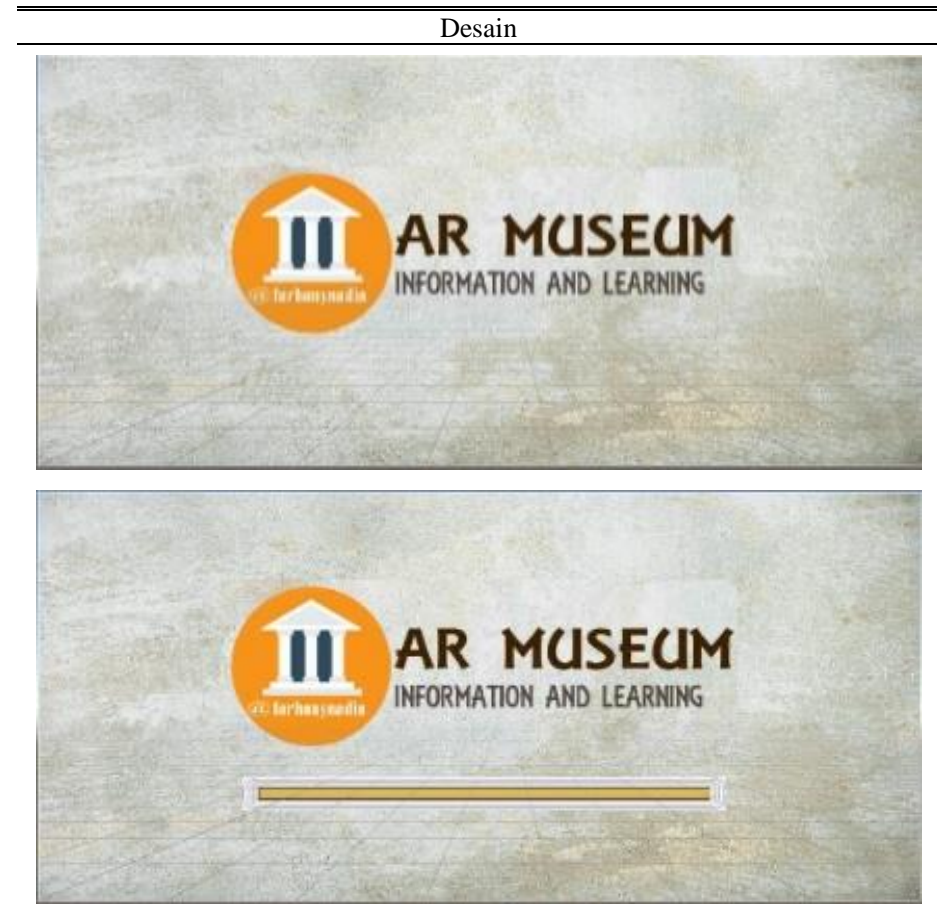

Keterangan

Splash Screen merupakan tampilan awal ketika pengguna membuka aplikasi.

Screen Loading merupakan tampilan yang memunculkan prosess loading untuk menuju ke menu utama

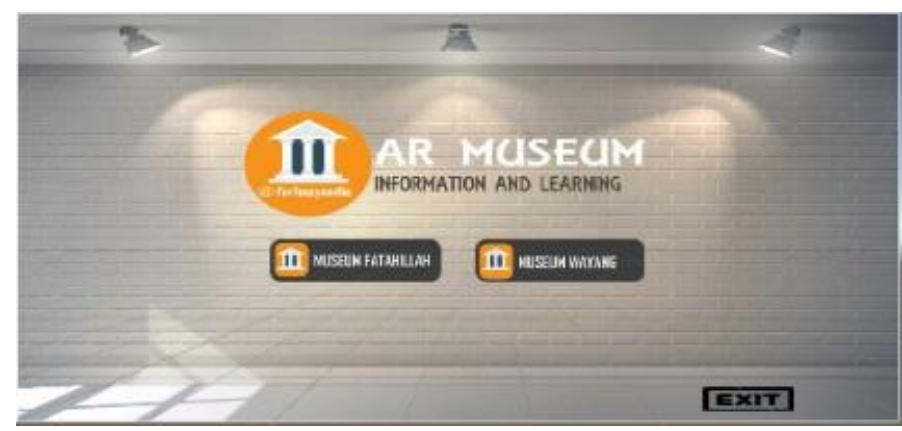

Menu Utama yang terdiri dari button Museum Fatahillah, Museum Wayang, jika ditekan akan menuju ke screen kamera AR museum dan button Exit yang berguna untuk keluar dari aplikasi

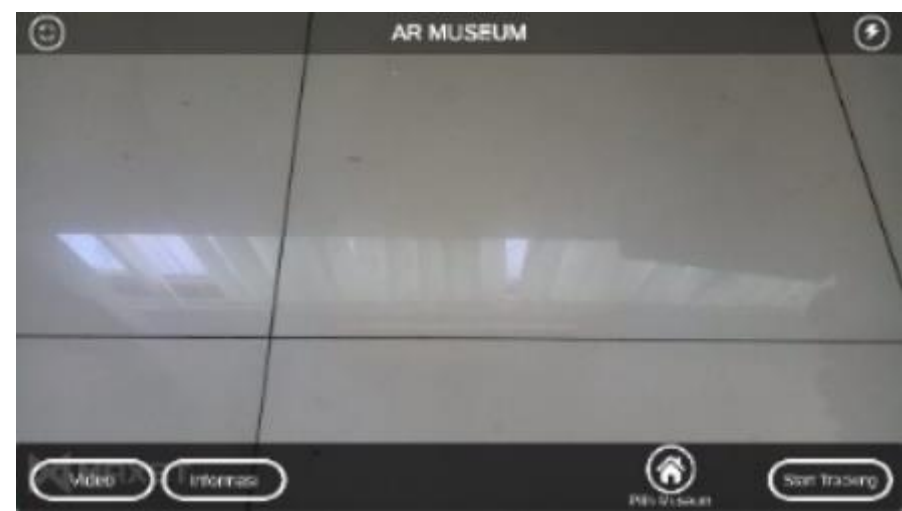

Terdapat juga button informasi dan video yang berguna untuk menampilkan penjelasan berupa teks dan video sebagai tambahan informasi, button pilih museum yang berguna untuk kembali ke menu utama. 


\section{B. Pengujian}

Pada tahap pengujian dimana proses pengoprasian aplikasi Augmented reality serta penerapan perangkat lunak pada keadaan yang sesungguhnya.

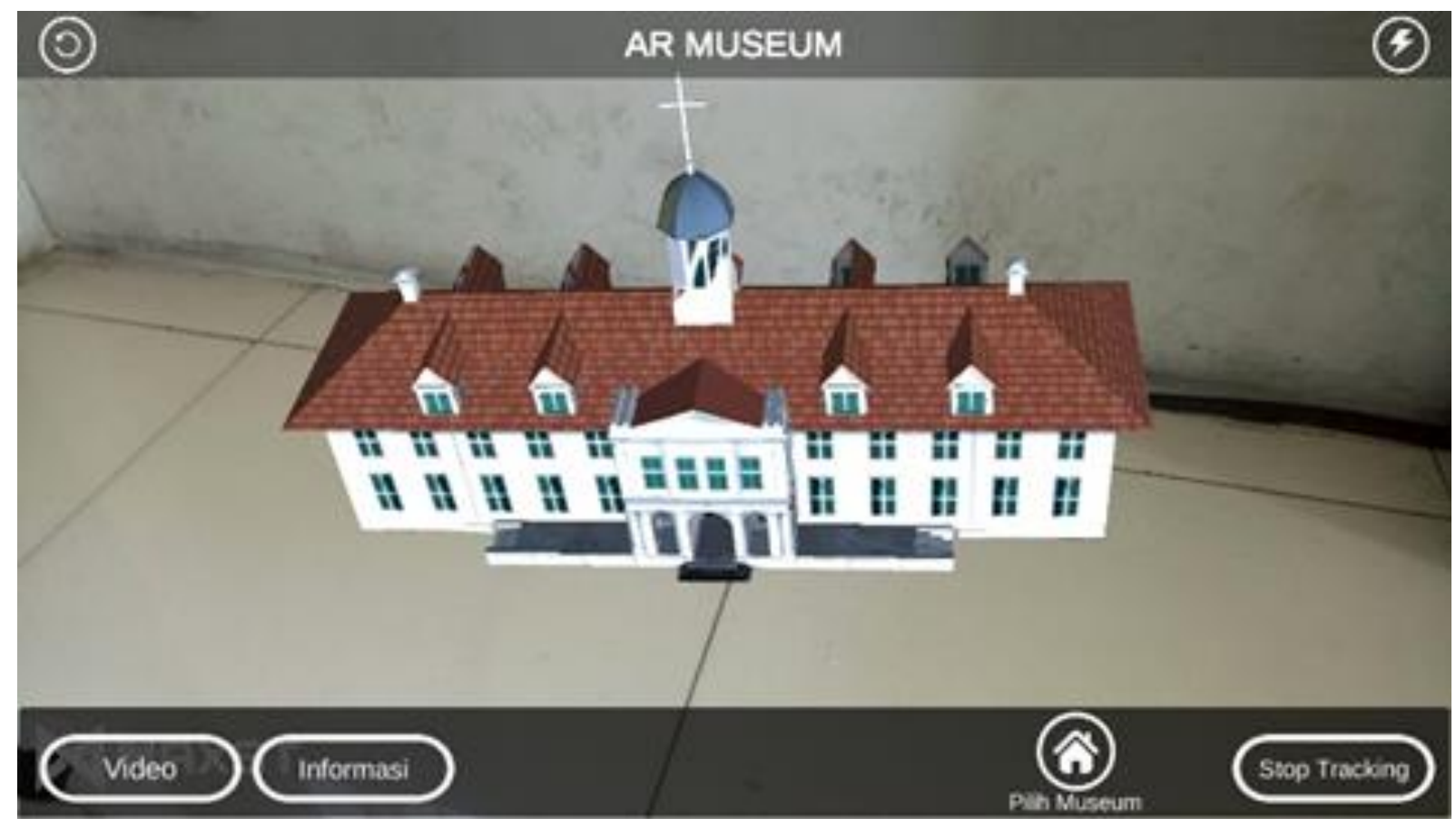

Gambar 3. Tampilan 3D Object Museum pada AR Kamera

Pada Gambar 3, pengguna menekan button Start Tracking lalu aplikasi memunculkan 3D Object Museum Fatahillah. dengan menggunakan metode Markerless, Object 3D bisa muncul di permukaan mana saja. File 3D Object yang dimunculkan yang mempunyai ekstensi .Obj [15].

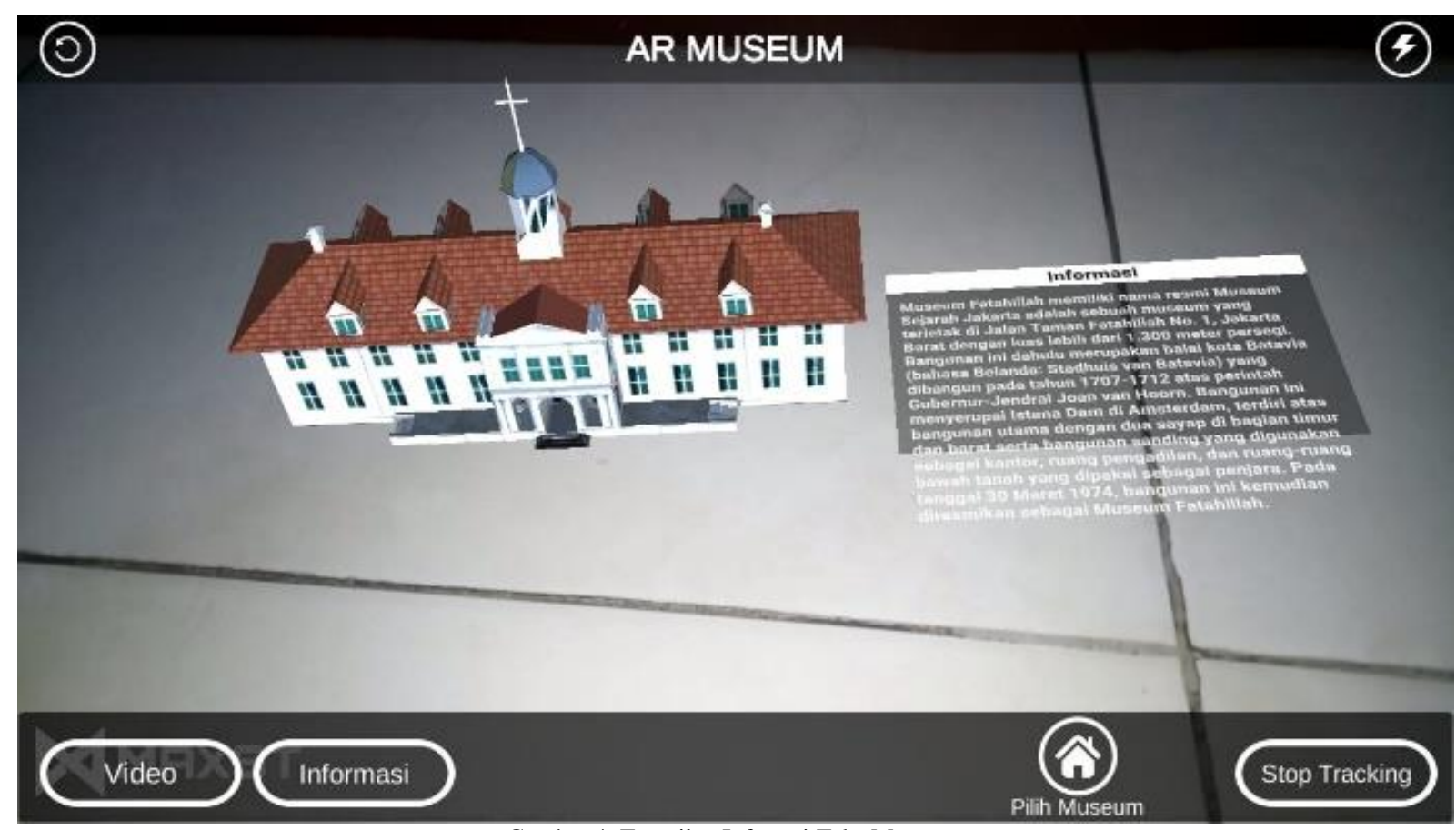

Gambar 4. Tampilan Informsi Teks Museum

Untuk infomasi berupa teks muncul ketika 3D Object dari museum telah muncul. Teks berupa penjelasan singkat dari museum yang dapat dibaca oleh pengguna. 


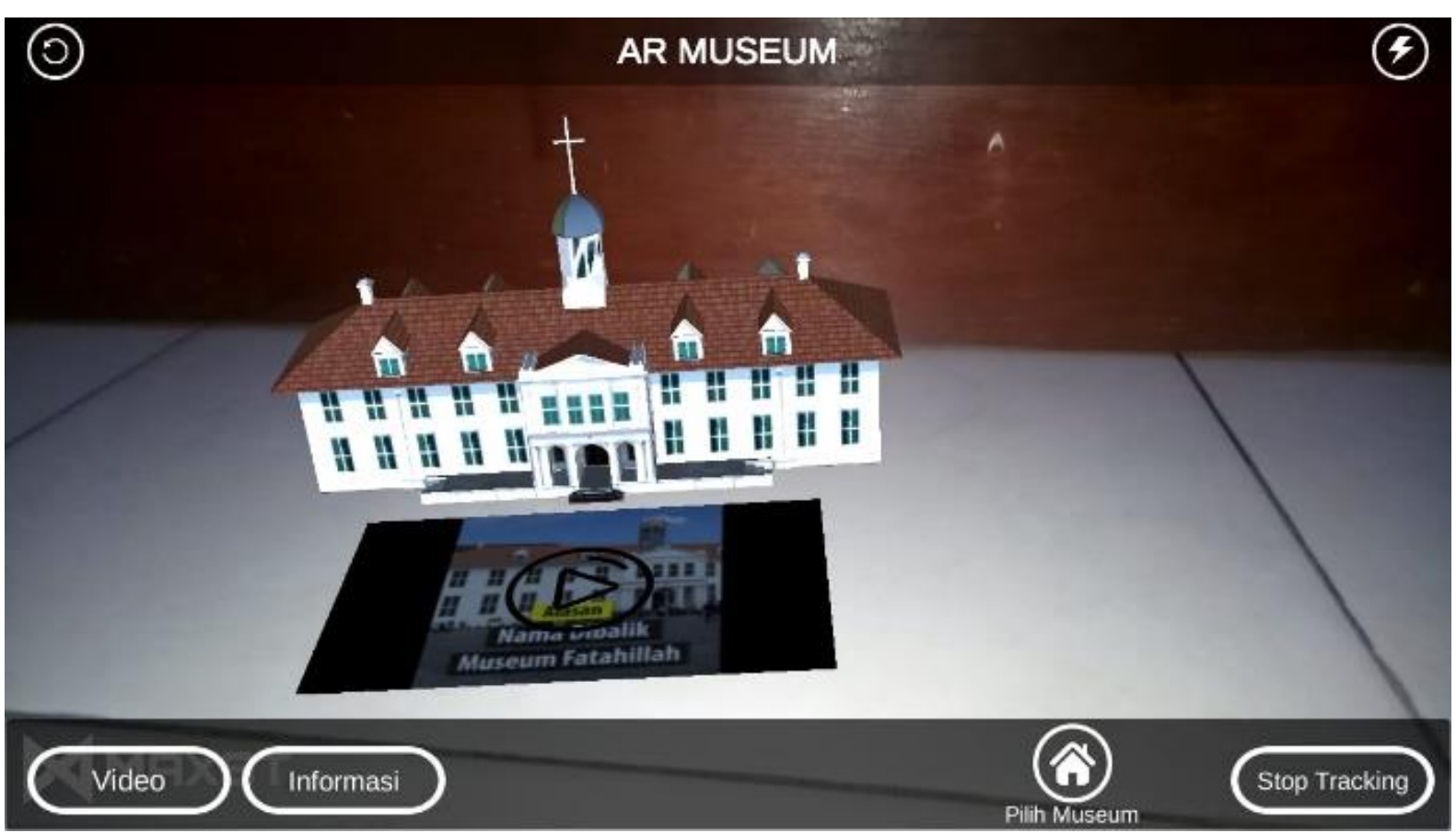

Gambar 5. Tampilan Infomasi Video Museum

Pada Gambar 5, Informasi berupa video bisa ditampilkan dengan menekan button video. Dan informasi bisa ditampilkan sesuai dengan perintah yang diinginkan.

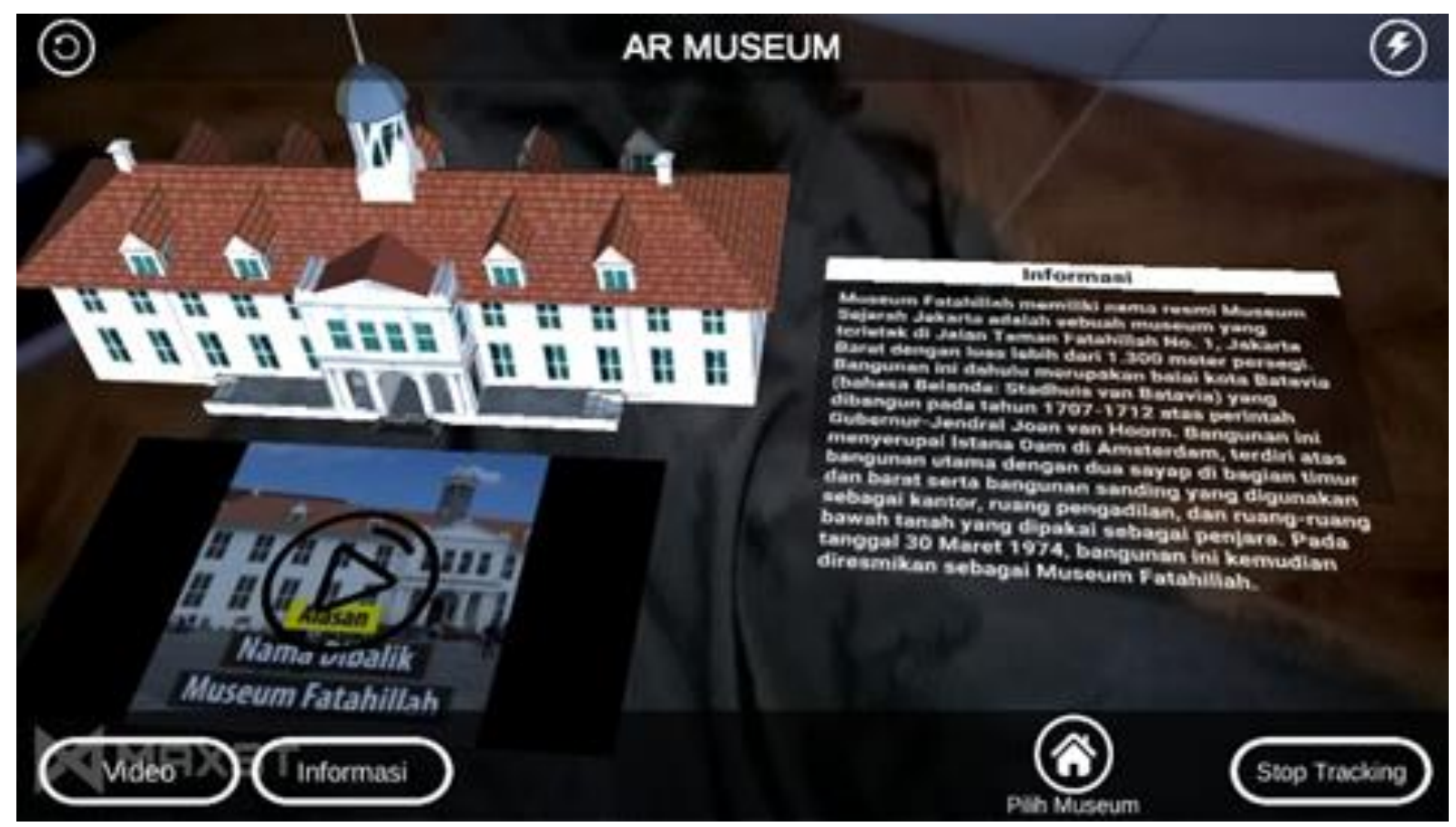

Gambar 6. Memunculkan Semua Perintah Aplikasi

Pada Gambar 6, untuk mengidentifikasi objek dibutuhkan perantara berupa kamera yang nantinya akan menyisipkan objek maya ke dalam dunia nyata dan pengguna tidak membutuhkan marker [16]. aplikasi ini menunjukan bahwa dapat memunculkan informasi yang sudah tersedia secara bersamaan tanpa menggunakan marker, yaitu menampilkan Object 3D, informasi teks, dan infomasi video berupa 3D Animasi. 
TABEL II

PENGUJian TERHADAP CAHAYA

\begin{tabular}{cccc}
\hline \hline Android & Gelap & Terang & Gelap dengan Flash \\
\hline v4.1.2 & Tidak Muncul & Muncul & Muncul \\
v5.1.1 & Tidak Muncul & Muncul & Muncul \\
v6.0.1 & Tidak Muncul & Muncul & Muncul \\
v7.2.1 & Tidak Muncul & Muncul & Muncul \\
\hline \hline
\end{tabular}

Pada pengujian terhadap cahaya dapat disimpulkan bahwa Object yang dihasilkan dapat muncul dalam keadaan cahaya terang, jika dalam keadaan gelap maka Object tidak dapat muncul. Tetapi aplikasi menyediakan bantuan berupa Flash yang berfungsi untuk memberikan bantuan cahay a pada kamera agar dapat memunculkan Object dalam keadaan gelap.

TABEL III

PENGUJIAN KONDISI LANDASAN 3D OBJECT

\begin{tabular}{ccc}
\hline \hline \multirow{2}{*}{ Android } & \multicolumn{2}{c}{ Landasan 3D Object } \\
& Rusak & Baik \\
\hline v4.1.2 & Berhasil & Berhasil \\
v5.1.1 & Berhasil & Berhasil \\
v6.0.1 & Berhasil & Berhasil \\
v7.2.1 & Berhasil & Berhasil \\
\hline \hline
\end{tabular}

Pada Tabel III, dapat disimpulkan versi Android yang telah di uji dengan kondisi landasan 3D Object yang rusak, yaitu keadaan landasan yang bergelombang atau tidak rata dapat memunculkan Object dengan baik. Dan pada landasan 3D Object yang baik (Rata) Object Museum pun dapat berhasil muncul.

TABEL IV

PENGUJIAN JARAK

\begin{tabular}{|c|c|c|c|c|}
\hline \multirow{2}{*}{ Android } & \multicolumn{4}{|c|}{ Jarak } \\
\hline & $>5 \mathrm{~cm}$ & $>50 \mathrm{~cm}$ & $<100 \mathrm{~cm}$ & $>100 \mathrm{~cm}$ \\
\hline $\mathrm{v} 4.1 .2$ & Berhasil & Berhasil & Berhasil & Cukup Berhasil \\
\hline v5.1.1 & Berhasil & Berhasil & Berhasil & Cukup Behasil \\
\hline v6.0.1 & Berhasil & Berhasil & Berhasil & Cukup Berhasil \\
\hline v7.2.1 & Berhasil & Berhasil & Berhasil & Cukup Berhasil \\
\hline
\end{tabular}

Pada tahap pengujian jarak, diketahui bahwa kamera AR dapat memunculkan Object 3D museum pada jarak minimal $5 \mathrm{~cm}-$ jarak $<100 \mathrm{~cm}$ secara berhasil, dan pada jarak $>100 \mathrm{~cm}$ Object Museum berhasil muncul dengan keterangan cukup berhasil, yaitu Object Museum terlihat kecil di ikuti perintah yang lainnya, seperti informasi teks dan video.

TABEL V.

Hasil Kuisioner PENGUJiAn PENGgunaAn APLIKASI

\begin{tabular}{|c|c|c|c|c|c|c|c|c|c|c|c|c|c|c|}
\hline \multirow{2}{*}{ No } & \multirow{2}{*}{ Pernyataan } & \multicolumn{5}{|c|}{ Jawaban User } & \multicolumn{5}{|c|}{ Skala Likert } & \multirow{2}{*}{$\begin{array}{l}\text { Total } \\
\text { Score }\end{array}$} & \multirow{2}{*}{$\begin{array}{c}\text { Skala } \\
\text { Likert }(\%)\end{array}$} & \multirow{2}{*}{ Interpretasi } \\
\hline & & STS & TS & $\mathrm{N}$ & $\mathrm{S}$ & SS & STS & $\mathrm{TS}$ & $\mathrm{N}$ & $\mathrm{S}$ & SS & & & \\
\hline 1 & $\begin{array}{l}\text { Informasi yang } \\
\text { ditampilkan menarik }\end{array}$ & 0 & 0 & 1 & 4 & 15 & 0 & 0 & 3 & 16 & 75 & 94 & $94 \%$ & $\begin{array}{l}\text { Sangat } \\
\text { Setuju }\end{array}$ \\
\hline 2 & $\begin{array}{l}\text { Pemahaman tentang } \\
\text { museum mudah } \\
\text { dimengerti }\end{array}$ & 0 & 0 & 2 & 9 & 9 & 0 & 0 & 6 & 36 & 45 & 87 & $87 \%$ & $\begin{array}{l}\text { Sangat } \\
\text { Setuju }\end{array}$ \\
\hline 3 & $\begin{array}{l}\text { User interface aplikasi } \\
\text { mudah di mengerti }\end{array}$ & 0 & 0 & 1 & 3 & 16 & 0 & 0 & 3 & 12 & 80 & 95 & $95 \%$ & $\begin{array}{l}\text { Sangat } \\
\text { Setuju }\end{array}$ \\
\hline 4 & $\begin{array}{l}\text { Penjelasan melalui } \\
\text { audio jelas }\end{array}$ & 0 & 0 & 2 & 4 & 15 & 0 & 0 & 6 & 16 & 75 & 97 & $97 \%$ & $\begin{array}{l}\text { Sangat } \\
\text { Setuju }\end{array}$ \\
\hline 5 & $\begin{array}{l}\text { Kemiripan object yang } \\
\text { dibangun sudah sesuai } \\
\text { dengan museum asli }\end{array}$ & 0 & 0 & 1 & 5 & 14 & 0 & 0 & 3 & 20 & 70 & 93 & $93 \%$ & $\begin{array}{l}\text { Sangat } \\
\text { Setuju }\end{array}$ \\
\hline \multicolumn{13}{|c|}{ Rata - rata } & $93,2 \%$ & $\begin{array}{l}\text { Sangat } \\
\text { Setuju }\end{array}$ \\
\hline
\end{tabular}

Berdasarkan hasil yang didapat pada Tabel V, rata - rata nilai yang di dapat 93,2\% dengan interpretasi 
sangat setuju, nilai tersebut mengartikan bahwa aplikasi telah sesuai dengan tujuan bahwa aplikasi dirancang sebagai media penyampaian informasi dengan menampilkan visual dan audio serta objek 3D.

\section{KESIMPULAN}

Berdasarkan hasil pengujian, terdapat beberapa kesimpulan untuk aplikasi Augmented reality sebagai Media Informasi Museum Fatahillah dan Museum Wayang berbasis Android. Aplikasi AR dapat menjadi alternatif dari masalah yang disebabkan oleh kurangnya media informasi, dari hasil rata - rata penggunaan aplikasi didapat 93,2\% yang mengartikan bahwa aplikasi yang dirancang telah sesuai dengan keinginan user. Aplikasi yang dirancang dapat digunakan padaAndroid $\geq$ v4.1.2 (Jelly Bean). kamera AR dapat memunculkan Object 3D pada jarak $>100 \mathrm{~cm}$ dan tanpa menggunakan marker dengan kelebihan Object dapat bergerak secara dynamis. Informasi dilengkapi sebuah video yang berupa Animasi tentang penjelasan museum, beberapa ruang dan benda di dalamnya.

\section{DAFTAR PUSTAKA}

[1] F. R. E. Geken, “Jumlah Pengunjung Objek Wisata Kota Tua Capai 50 Ribu Orang,” TEMPO.CO, 2019. [Online]. Available: https://metro.tempo.co/read/1212569/jumlah-pengunjung-objek-wisata-kota-tua-capai-50-ribu-orang/full\&view=ok.

[2] L. S. B. Ginting, M. Pamungkas, and Y. R. Ginting, "Metode Markerless Untuk Membangun Aplikasi Pemandu Wisata Wilayah Ciayumajakuning Berbasis Mobile Android," J. Teknol. dan Inf., vol. 7, no. 2, pp. 65-78, 2017.

[3] H. Vitono, H. Nasution, and H. Anra, "Implementasi Markerless Augmented Reality Sebagai Media Informasi Koleksi Museum Berbasis Android (Studi Kasus : Museum Kalimantan Barat),” Univ. Tanjungpura Pontianak, vol. 2, no. 4, pp. 239-245, 2016.

[4] A. A. K. Oka Sudana, K. S. Wibawa, and I. M. A. D. Tirtha, "Learning media of Balinese script writing based on augmented reality," J. Theor. Appl. Inf. Technol., vol. 90, no. 1, pp. 31-39, 2016.

[5] F. N. Afif and A. H. Basori, "Orientation Control for Indoor Virtual Landmarks based on Hybrid-based Markerless Augmented Reality," Procedia - Soc. Behav. Sci., vol. 97, pp. 648-655, 2013.

[6] I. G. G. R. Wiradarma, I. G. M. Darmawiguna, and I. M. G. Sunarya, "Pengembangan Aplikasi Markerless Augmented Reality Balinese Story 'I Gede Basur,"' J. Nas. Pendidik. Tek. Inform., vol. 6, no. 1, p. 30, 2017.

[7] I. G. Aditya Nugraha, I. K. G. D. Putra, and I. M. Sukarsa, "Rancang Bangun Aplikasi Augmented Reality Museum Bali Berbasis Android Studi Kasus Gedung Karangasem dan Gedung Tabanan,” Lontar Komput. J. Ilm. Teknol. Inf., vol. 7, no. 2, p. 93, 2016.

[8] R. R. Relifian and S. C. Wibawa, "Pengembangan Media Pembelajaran Aplikasi Pengambilan Sudut Gambar Menggunakan Metode Markerless Augmented Reality Berbasis android," J. IT-EDU, vol. 3, no. 1, pp. 1-8, 2018.

[9] Y. A. Pramana, K. C. Brata, and A. H. Brata, "Pembangunan Aplikasi Augmented Reality untuk Pengenalan Benda di Museum Berbasis Android ( Studi Kasus : Museum Blambangan Banyuwangi )," J. Pengemb. Teknol. Inf. dan Ilmu Komput., vol. 2, no. 5, pp. 2034-2042, 2018 .

[10] N. M. Sudiartini, I. G. M. Darmawiguna, and I. M. G. Sunarya, "Pengembangan Aplikasi Markerless Augmented Reality Balinese Story "Calon Arang,"' J. Pendidik. Teknol. dan Kejuru., vol. 13, no. 2, 2016.

[11] L. Carozza, D. Tingdahl, F. Bosché, and L. van Gool, "Markerless vision-based augmented reality for urban planning," Comput. Civ. Infrastruct. Eng., vol. 29, no. 1, pp. 2-17, 2014.

[12] M. E. Kesehatan and G. B. Anak, "Penerapan Teknologi Augmented Reality Sebagai Model," Citec J., vol. 2 , no. 1, 2014.

[13] M. Jumarlis and M. Mirfan, "Implementation of Markerless Augmented Reality Technology Based on Android to Introduction Lontara in Marine Society,” IOP Conf. Ser. Earth Environ. Sci., vol. 156, no. 1, 2018.

[14] B. A. S. Zwingly Ch Rawis, Virginia Tulenan, "Penerapan Augmented Reality Berbasis Android Untuk Mengenalkan Pakaian Adat Tountemboan,” J. Early Child. Teach. Educ., vol. 19, no. 3, pp. 227-233, 1998.

[15] K. N. E. Aldi Apriansyah, Dhimas Mulia Anugraha, Galuh Prakoso, Rudi, and Priyana, “Aplikasi Pengenalan Hewan dengan Teknologi Marker Less Augmented Reality Berbasis Android,” DOUBLECLICK J. Comput. Inf. Technol., vol. 1, no. 1, p. 1, 2017.

[16] G. E. Saputra and E. Pratama, "Perancangan Aplikasi Pengenalan Negara-Negara Pendiri Asean Dengan Penerapan Augmented Reality Menggunakan Metode Markerless Pada Smartphone Berbasis Android,” J. Ilm. KOMPUTASI, vol. 17, no. 1, pp. 63-73, 2012. 